\title{
TSH reference range in older adults: a Brazilian study
}

\author{
Valores de referência do TSH em indivíduos \\ idosos: um estudo brasileiro
}

Pedro Weslley Rosario ${ }^{1,2}$, Maria Regina Calsolari²

\begin{abstract}
Objective: To establish serum TSH reference values for a population of Brazilian elderly, and to compare them to those found in the adult population. Subjects and methods: Healthy volunteers aged 70 to 85 years, without known thyroid disease or risk factors for thyroid dysfunction, who did not use any medication that could potentially interfere with TSH, were selected. Subjects with goiter, palpable thyroid nodules, anti-thyroperoxidase antibodies, or altered free T4 were excluded. The sample consisted of 360 older adults (180 per sex). Results: TSH values corresponding to the $2.5^{\text {th }}$ and $97.5^{\text {th }}$ percentile of the sample were 0.2 and $4.62 \mathrm{mIU} / \mathrm{L}$, respectively. TSH $>2.5 \mathrm{mIU} / \mathrm{L}$ was seen in $25.26 \%$ of the volunteers, $>3 \mathrm{mIU} / \mathrm{L}$ in $15.26 \%$, and $>4 \mathrm{mIU} / \mathrm{L}$ in $6.1 \%$ of them. TSH values were slightly higher than those previously reported for adults (1860 years). Conclusion: This study suggests an upper limit for normalTSH of approximately 4.6 mIU/L for the Brazilian elderly population. Arq Bras Endocrinol Metab. 2014;58(4):389-93
\end{abstract}

\section{Keywords}

TSH; upper limit; older adults

\section{RESUMO}

Objetivo: Estabelecer os valores de referência doTSH sérico em uma população idosa brasileira e compará-los ao encontrado na população adulta. Sujeitos e métodos: Foram selecionados voluntários saudáveis; com idade entre 70 e 85 anos; sem doença tireoidiana conhecida ou fatores de risco para disfunção tireoidiana; sem uso de medicamentos potencialmente interferentes no TSH. Indivíduos com bócio, nódulo tireoidiano palpável, anticorpos antitireoperoxidase ou T4 livre alterado foram excluídos. A amostra foi composta de 360 participantes (180 de cada sexo). Resultados: Os valores correspondentes aos percentis 2,5 e 97,5 da amostra foram 0,2 e $4,62 \mathrm{mIU} / \mathrm{L}$, respectivamente. TSH > 2,5 mIU/L foi visto em $25,26 \%$ dos indivíduos, $>3 \mathrm{mIU} / \mathrm{L}$ em $15,26 \%$ e $>4 \mathrm{mIU} / \mathrm{L}$ em $6,1 \%$. Os valores deTSH foram discretamente maiores que os encontrados previamente em indivíduos adultos (18-60 anos). Conclusão: Nosso estudo sugere para a população idosa brasileira o limite superior normal doTSH de aproximadamente 4,6 mIU/L. Arq Bras Endocrinol Metab. 2014;58(4):389-93

Descritores

TSH; limite superior; idosos
Graduate Studies Program, Santa Casa de Belo Horizonte, Belo Horizonte, MG, Brazil

${ }^{2}$ Endocrinology Service, Santa Casa de Belo Horizonte, Belo Horizonte, MG, Brazil

\section{INTRODUCTION}

$I^{\prime}$ $\mathrm{n}$ addition to the discussion about reducing the upper limit for normal TSH, different (higher) values have been reported for older adults (1). In the NHANES III including 13,344 subjects older than 12 years (pregnant women were excluded) without known thyroid disease or other diseases demonstrated by laboratory tests, and without anti-thyroid antibo- dies, the $97.5^{\text {th }}$ percentile of TSH was $4.12 \mathrm{mIU} / \mathrm{L}$ for the entire sample, but 5.9 and $7.49 \mathrm{mIU} / \mathrm{L}$ for the age groups of 70-79 years and $\geq 80$ years, respectively (1).

The idea is that normal serum TSH is higher in older adults is in contrast with some previous studies. A lower pituitary response (TSH elevation) to a decrease of serum T4 is known in this age group $(2,3)$, with higher baseline TSH levels and paradoxical lower response to 
the stimulus (hypothyroxinemia). A reduction, rather than an increase, in TSH was always considered to be a physiological alteration related to aging (4-8). Finally, other studies did not report higher TSH levels in older adults $(4,9-15)$, but showed a trend of an inverse relationship between age and TSH $(4,9,13)$.

These data have to be considered together with the limitations of the NHANES III (1). The presence of thyroid disease, goiter, or use of thyroid or other medications was self-reported and a detailed history was not obtained at the time of examination (16). On the basis of the same data, Spencer and cols. (17) concluded that the higher TSH levels seen in older adults did not appear to reflect the influence of age per se, but rather a higher prevalence of occult thyroid disease. Unfortunately, Surks and Hollowell (1) did not determine the nature of the relationship between T4 and TSH in the populations studied (18), which could provide evidence of whether the increase in TSH reflects occult thyroid dysfunction. Regardless of this, all patients were from the United States and the findings may not be applicable to other populations (1).

It is clear that further studies employing adequate sample selection, and involving other populations are needed to evaluate TSH levels in older adults. In this study, we evaluated the normal reference range of TSH in a population of Brazilian older adults (70-85 years) using rigorous sample selection (personal interview, clinical examination, and measurement of autoantibodies and free T4). In addition, we compared the results with those obtained for adults ( $\leq 60$ years) of the same population in a previous study (19).

\section{SUBJECTS AND METHODS}

The origin of the subjects, selection criteria, protocol, method for the definition of normal reference range, and immunoassays were the same as those used in a previous study (19). The two studies differed in the age of the participants: 18 to 60 years (19) and 70 to 85 years (present study).

The population studied was from the metropolitan region of Belo Horizonte (Minas Gerais, Brazil). Subjects were selected from clinical routine practice. Apparently healthy volunteers of both genders were initially interviewed and examined. Subjects who met the clinical criteria shown in table 1 were selected. Next, serum samples were obtained from the selected subjects in the morning (at about 8 a.m.) after an 8- to 10-h fast, and anti-thyroperoxidase antibodies (TPOAb), free T4 and TSH were measured. Subjects presenting positive TPOAb and/or altered free T4 were excluded. Ultrasonography (US) was not performed in all subjects because of the following reasons: US is not required by the National Academy of Clinical Biochemistry (NACB) to establish reference intervals for thyrotropin (TSH) and thyroid hormones (20); previous studies have shown no change in the normal reference range for TSH when subjects with ultrasonographic anomalies were excluded from the initial sample $(9,21-23)$, a finding also demonstrated in a previous study from our group (24); no consensus exists regarding the ultrasonographic findings associated with Hashimoto thyroiditis (9,21-23); and most subjects with chronic thyroiditis without circulating TPOAb are identified based on a history of autoimmune disease, family history of thyroid disease, or presence of goiter, which were exclusion criteria in this study. However, US was performed in subjects with TSH $\geq 4$ $\mathrm{mIU} / \mathrm{L}$ to evaluate the presence of occult chronic thyroiditis. A total of 730 volunteers were recruited; from these, $716(98 \%)$ agreed to be interviewed and examined, and 356 were excluded because they did not fulfill the selection criteria (Table 1). The sample was considered to be complete after the inclusion of 180 subjects of each gender [pre-defined and larger than that required by the NACB (20)]. The median age of the 360 volunteers was 77 years and $32(8.9 \%)$ subjects were smokers. The age distribution of the sample was: 70 to 80 years $(\mathrm{n}=239)$ and $\geq 80$ years $(\mathrm{n}=121)$. The study was approved by the local Research Ethics Committee.

Table 1. Inclusion criteria

Clinical criteria

Age 70 to 85 years

Absence of thyroid disease, no current or previous treatment with antithyroid drugs or L-T4, no history of ${ }^{131}$ I therapy or thyroidectomy

No use of potentially interfering medications, such as dopaminergic agonists or antagonists, neuroleptics, corticosteroids, estrogen, amiodarone, interferon, lithium, anticonvulsants, metformin, octreotide; or recent (in the past 8 weeks) exposure to iodinated contrast agents

No history of neck external radiotherapy

Absence of type 1 diabetes or other autoimmune diseases

No family history of thyroid disease

No acute disease in the last 3 months

Absence of goiter or any palpable thyroid anomaly

Complementary criteria

TPOAb negative

Normal free T4

TPOAb: thyroperoxidase antibodies. 
TSH was measured with a chemiluminescent assay (Immulite 2000, Diagnostic Products Corporation, Los Angeles, CA), with reference values of 0.4$4 \mathrm{mIU} / \mathrm{L}$, functional sensitivity of $0.02 \mathrm{mIU} / \mathrm{L}$, and intra- and interassay coefficients of variation $<7 \%$ for values ranging from 0.1 to $40 \mathrm{mIU} / \mathrm{L}$. TPOAb and free T4 were also measured with a chemiluminescent assay (Immulite 2000, Diagnostic Products Corporation, Los Angeles, CA), with reference values of up to $35 \mathrm{IU} / \mathrm{mL}$ and 0.8 to $2.0 \mathrm{ng} / \mathrm{dL}$, respectively.

Ultrasonography was performed with a linear multifrequency $12-\mathrm{MHz}$ transducer for morphological analysis. The images were analyzed by experienced professionals who were unaware of the thyroid status of the patient. Diffuse hypoechogenicity was used as a criterion for the definition of autoimmune thyroiditis.

The normal reference range for TSH was defined as follows: 1) $2.5^{\text {th }}$ and $97.5^{\text {th }}$ percentiles of the values obtained for the sample; 2) logarithmic transformation of the values obtained, calculation of the mean $\pm 1.96 \mathrm{SD}$ of these values, and exponentiation to obtain the limits corresponding to the original scale (20). The Spearman correlation test was used to analyze the correlation between TSH and age. The nonparametric Kruskal-Wallis test and the parametric Shapiro-Wilk test were used to compare TSH values between groups. Fisher's exact test or the $\mathrm{X}^{2}$ test was used to detect differences in the proportion of cases. $\mathrm{P}$ value $<0.05$ was considered to be statistically significant.

\section{RESULTS}

The distribution of TSH values in the sample is shown in figure 1. Mean, median, minimum, maximum, and $2.5^{\text {th }}$ and $97.5^{\text {th }}$ percentiles of the values obtained were $1.85,1.8,0.2,5.84,0.31$ and $4.62 \mathrm{mIU} / \mathrm{L}$, respectively. TSH $>2.5 \mathrm{mIU} / \mathrm{L}$ was seen in $25.26 \%$ of the participants, $>3 \mathrm{mIU} / \mathrm{L}$ in $15.26 \%$, and $>4 \mathrm{mIU} / \mathrm{L}$ in $6.1 \%$ of them. There was no difference in TSH levels between men versus women $(\mathrm{p}=0.3)$, smokers versus non-smokers $(\mathrm{p}=0.43)$, or subjects aged $70-79$ years versus $\geq 80$ years $(\mathrm{p}=0.64)$; TSH levels were also not correlated with age $(\mathrm{p}=0.4)$.

The upper reference limit (mean + 1.96 SD) was estimated for the log-transformed data, which were exponentiated back to the original scale. The resulting value $(4.65 \mathrm{mIU} / \mathrm{L})$ was very close to the $97.5^{\text {th }}$ percentile of TSH values $(4.62 \mathrm{mIU} / \mathrm{L})$.

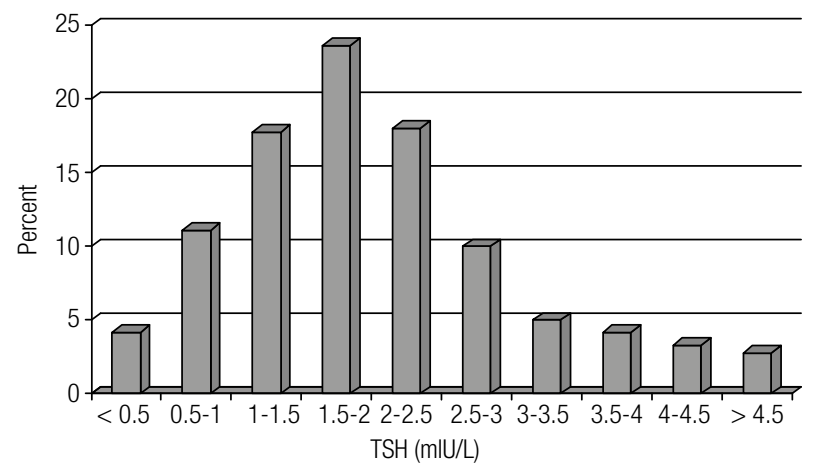

Figure 1. TSH distribution in the entire cohort $(n=360)$.

It should be noted that none of the 22 subjects with $\mathrm{TSH} \geq 4 \mathrm{mIU} / \mathrm{L}$ and submitted to US presented alterations suggestive of chronic thyroiditis.

The comparison of TSH values between adults aged 18 to 60 years (19) and older people (70-85 years) is shown in table 2 .

Table 2. Comparison of TSH values between adults [18-60 years (19)] and older people (70-85 years)

\begin{tabular}{lcc}
\hline TSH/Age group & $\mathbf{1 8 - 6 0}$ years (19) & $\mathbf{7 0 - 8 5}$ years (present study) \\
\hline Mean* & $1.52 \mathrm{mlU} / \mathrm{L}$ & $1.85 \mathrm{mlU} / \mathrm{L}$ \\
Median & $1.4 \mathrm{mlU} / \mathrm{L}$ & $1.8 \mathrm{mlU} / \mathrm{L}$ \\
$97.5^{\text {th }}$ percentile & $3.24 \mathrm{mlU} / \mathrm{L}$ & $4.62 \mathrm{mlU} / \mathrm{L}$ \\
Mean $+1.96 \mathrm{SD}$ & $3.27 \mathrm{mlU} / \mathrm{L}$ & $4.65 \mathrm{mlU} / \mathrm{L}$ \\
$>2.5 \mathrm{mlU} / \mathrm{L}^{*}$ & $9.1 \%$ & $25.2 \%$ \\
$>3 \mathrm{mlU} / \mathrm{L}^{*}$ & $3.1 \%$ & $15.2 \%$ \\
$>4 \mathrm{mlU} / \mathrm{L}^{*}$ & $0.6 \%$ & $6.1 \%$ \\
${ }^{*} \mathrm{p}<0.05$. & &
\end{tabular}

\section{DISCUSSION}

To our knowledge, this is the first study evaluating the normal reference range for TSH in a population of Brazilian older adults. In addition, the selection criteria, number of participants (20), and adequate sample selection should be highlighted.

Similar to other studies $(1,25)$, higher TSH concentrations were observed in older people when compared to adults. It is unlikely that this difference is due to a higher prevalence of occult thyroid disease in this age group since rigorous criteria were adopted for its exclusion. Although we cannot rule out the possibility of chronic thyroiditis in the absence of circulating TPOAb, we do not believe that this condition plays a relevant role in the sample selected. First, TPOAb show high sensitivity in detecting chronic thyroiditis, and many patients with thyroiditis without TPOAb 
have family history of thyroid disease, personal history of autoimmune disease or goiter, and these conditions were exclusion criteria in the present study. Second, if cases of occult thyroiditis exist, it would be expected that they are more frequent among subjects with elevated TSH. However, US did not suggest this diagnosis in subjects with $\mathrm{TSH} \geq 4 \mathrm{mIU} / \mathrm{L}$. In addition, previous studies found no difference in the upper limit of TSH after excluding patients with altered US $(9,21$ 23 ), suggesting that these cases of inapparent thyroiditis (negative TPOAb) have no significant impact.

The hypotheses to explain the physiological elevation of TSH in older adults would, in fact, be a reduction in pituitary sensitivity to thyroid hormones (altered setpoint), higher production of isoforms with lower biological activity, and a decline in the functional capacity of the thyroid with age.

Although confirming higher TSH concentrations in older adults, the values found in this study are lower than those reported in the NHANES III (1). This discrepancy can be readily explained by population differences (genetic background, ethnicity, iodine sufficiency, among others). However, we believe that that NHANES values might be overestimated due to the less rigorous selection of the reference population. The presence of thyroid disease, goiter, or use of thyroid or other medications was self-reported, and a detailed history was not obtained at the time of examination (16). Supporting the failure in the selection to exclude occult thyroid diseases, 93 subjects included in the reference population had TSH $>10 \mathrm{mIU} / \mathrm{L}$, range 10.4 to $83 \mathrm{mIU} / \mathrm{L}(26)$. Another recent study (from Scotland) that was larger than the NHANES III and did not include TPOAb as a selection criterion, a fact that may have overestimated TSH values, reported an upper limit for normal TSH of $4.96 \mathrm{mIU} / \mathrm{L}$ in the age group of $70-80$ years $(25)$, very similar to the limit observed here $(4.62 \mathrm{mIU} / \mathrm{L})$.

Serum concentrations of TSH $<4.5 \mathrm{mIU} / \mathrm{L}$ are acceptable even in adults ( $<70$ years). Similarly, TSH levels $>10 \mathrm{mIU} / \mathrm{L}$ are considered to be altered, irrespective of age (26). Therefore, the adoption of a different limit for the elderly population would have an impact on subjects with intermediate TSH levels, who may be erroneously classified as having subclinical hypothyroidism ( $\mathrm{SCH}$ ) or as inadequately treated if undergoing L-T4 replacement therapy; however, the representativeness of these cases is variable $(1,25,27)$. Fortunately, even if $\mathrm{SCH}$ is erroneously diagnosed in older adults due to the lack of a specific TSH limit for age, it is possible that only few patients will be treated. In this age group, the repercussions of SCH seem to be less consistent $(28,29)$, and treatment of patients with $\mathrm{TSH}<10 \mathrm{mIU} / \mathrm{L}$ apparently has no benefits $(29,30)$.

This study suggests an upper limit for normal TSH of approximately $4.6 \mathrm{mIU} / \mathrm{L}$ for the Brazilian elderly population (70-85 years).

Disclosure: no potential conflict of interest relevant to this article was reported.

\section{REFERENCES}

1. Surks MI, Hollowell JG. Age-specific distribution of serum thyrotropin and antithyroid antibodies in the U.S population: implications for the prevalence of subclinical hypothyroidism. J Clin Endocrinol Metab. 2007;92:4575-82.

2. Carle A, Laurberg P, Pedersen IB, Perrild H, Ovesen L, Rasmussen LB, et al. Age modifies the pituitary TSH response to thyroid failure. Thyroid. 2007;17:139-44.

3. Over R, Mannan S, Nsouli-Maktabi H, Burman KD, Jonklaas J. Age and the thyrotropin response to hypothyroxinemia. J Clin Endocrinol Metab. 2010;95:3675-83.

4. Mariotti S, Franceschi C, Cossarizza A, Pinchera A. The aging thyroid. Endocr Rev. 1995;16:686-715.

5. Stan M, Morris JC. Thyrotropin-axis adaptation in aging and chronic disease. Endocrinol Metab Clin N Am. 2005;34:973-92.

6. Adler SM, Burman KD. Abnormalities in thyroid function parameters and subclinical thyroid disease in the elderly: a brief review. 2007. Available at: www.hotthyroidology.com

7. Peeters RP. Thyroid hormones and aging. Hormones (Athens). 2008;7:28-35.

8. Mitrou P, Raptis SA, Dimitriadis G. Thyroid disease in older people. Maturitas. 2011;70:5-9.

9. Volzke H, Alte D, Kohlmann T, Ludemann J, Nauck M, John U, et al. Reference intervals of serum thyroid function tests in a previously iodine-deficient area. Thyroid. 2005;15:279-85.

10. Hershman JM, Pekary AE, Berg L, Solomon DH, Sawin CT. Serum thyrotropin and thyroid hormone levels in elderly and middleaged euthyroid persons. J Am Geriatr Soc. 1993;41:823-8.

11. Davey R. Thyroxine, thyrotropin, and age in a euthyroid hospital patient population. Clin Chem. 1997;43:2143-8.

12. Huang CC, Chen YC, Chen LK, Hwang SJ, Lin HD. Relationship between age and serum thyrotropin among asymptomatic older people in Taiwan. Arch Gerontol Geriatr. 2010;51:117-20.

13. Hoogendoorn $E H$, Hermus $A R$, de Vegt $F$, Ross $H A$, Verbeek $A L$, Kiemeney $L A$, et al. Thyroid function and prevalence of anti-thyroperoxidase antibodies in a population with borderline sufficient iodine intake: influences of age and sex. Clin Chem. 2006;52:104-11.

14. Marwaha RK, Tandon N, Ganie MA, Mehan N, Sastry A, Garg MK, et al. Reference range of thyroid function (FT3, FT4 and TSH) among Indian adults. Clin Biochem. 2013;46:341-5.

15. Tunbridge WM, Evered DC, Hall R, Appleton D, Brewis M, Clark F, et al. The spectrum of thyroid disease in a community: the Whickham survey. Clin Endocrinol (Oxf). 1977;7:481-93.

16. Hollowell JG, Staehling NW, Flanders WD, Hannon WH, Gunter EW, Spencer CA, et al. Serum TSH, T4, and thyroid antibodies in the United States population (1988 to 1994): National Health and Nutrition Examination Survey (NHANES III). J Clin Endocrinol Metab. 2002;87:489-99. 
17. Spencer CA, Hollowell JG, Kazarosyan M, Braverman LE. National Health and Nutrition Examination Survey III thyroid-stimulating hormone (TSH)-thyroperoxidase antibody relationships demonstrate that TSH upper reference limits may be skewed by occult thyroid dysfunction. J Clin Endocrinol Metab. 2007;92:4236-40.

18. Fatourechi V. Upper limit of normal serum thyroid-stimulating hormone: a moving and now an aging target? J Clin Endocrinol Metab. 2007;92:4560-2.

19. Rosario PW, Xavier AC, Calsolari MR. TSH reference values for adult Brazilian population. Arq Bras Endocrinol Metabol. 2010;54:603-6.

20. Baloch Z, Carayon P, Conte-Devolx B, Demers LM, Feldt-Rasmussen $\mathrm{U}$, Henry JF, et al. Laboratory medicine practice guidelines. Laboratory support for the diagnosis and monitoring of thyroid disease. Thyroid. 2003;13:3-126.

21. Zöphel K, Wunderlich G, Grüning T, Koch R, Döge H, Kotzerke J. Where does subclinical hypothyroidism start? Implications for the definition of the upper reference limit for thyroid stimulating hormone (TSH). Nuklearmedizin. 2005;44:56-61.

22. Hamilton TE, Davis S, Onstad L, Kopecky KJ. Thyrotropin levels in a population with no clinical, autoantibody, or ultrasonographic evidence of thyroid disease: implications for the diagnosis of subclinical hypothyroidism. J Clin Endocrinol Metab. 2008;93:1224-30.

23. Kratsch J, Fiedler GM, Leichtle A, Brugel M, Buchbinder S, Otto $L$, et al. New reference intervals for thyrotropin and thyroid hormones based on National Academy of Clinical Biochemistry criteria and regular ultrasonography of the thyroid. Clin Chem. 2005;51:1480-6.
24. Borges MAR, Rosario PW, Purisch S. Normal serum TSH for our adult population. Congresso Mineiro de Endocrinologia 2007 (Abstract).

25. Vadiveloo T, Donnan PT, Murphy MJ, Leese GP. Age- and genderspecific TSH reference intervals in people with no obvious thyroid disease in Tayside, Scotland: The Thyroid Epidemiology, Audit, and Research Study (TEARS). J Clin Endocrinol Metab. 2013;98:1147-53.

26. Boucai L, Hollowell JG, Surks MI. An approach for development of age-, gender-, and ethnicity-specific thyrotropin reference limits. Thyroid. 2011;21:5-11.

27. Kahapola-Arachchige KM, Hadlow N, Wardrop R, Lim EM, Walsh JP. Age-specific TSH reference ranges have minimal impact on the diagnosis of thyroid dysfunction.Clin Endocrinol (Oxf). 2012;77:773-9.

28. Ochs N, Auer R, Bauer DC, Nanchen D, Gussekloo J, Cornuz J, et al. Meta-analysis: subclinical thyroid dysfunction and the risk for coronary heart disease and mortality. Ann Intern Med. 2008;148:832-45.

29. Sgarbi JA, Teixeira PFS, Maciel LMZ, Mazeto GMFS, Vaisman M, Montenegro Jr. RM, et al. The Brazilian consensus for the clinical treatment of subclinical hypothyroidism in adults: recommendations of the Thyroid Department of the Brazilian Society of Endocrinology and Metabolism. Arq Bras Endocrinol Metabol. 2013;57:166-83.

30. Razvi S, Weaver JU, Butler TJ, Pearce SH. Levothyroxine treatment of subclinical hypothyroidism, fatal and nonfatal cardiovascular events, and mortality. Arch Intern Med. 2012;172:811-7. 